\title{
Developmental Expression of the 43K and 58K Postsynaptic Membrane Proteins and Nicotinic Acetylcholine Receptors in Torpedo Electrocytes
}

\author{
William J. LaRochelle, ${ }^{1, a}$ Veit Witzemann, ${ }^{2, b}$ Wolfgang Fiedler, ${ }^{2}$ and Stanley C. Froehner ${ }^{1}$ \\ 'Department of Biochemistry, Dartmouth Medical School, Hanover, New Hampshire 03756, and ${ }^{2}$ Abteilung Neurochemie, \\ Max-Planck-Institut fur biophysikalische Chemie, Gottingen, FRG
}

\begin{abstract}
The expression of the postsynaptic 43-kDa and 58-kDa proteins and actin during development of the Torpedo marmorata electric organ was compared to that of nicotinic acetylcholine receptors (AChRs). Western blot analysis demonstrates that AChRs and proteins of $43 \mathrm{kDa}$ (43K protein) and $58 \mathrm{kDa}$ (58K protein) are all present prior to synaptogenesis. Subsequently, levels of all 3 synaptic proteins increase dramatically during differentiation and innervation of electrocytes. In contrast, actin is present in relatively high concentrations at early times and decreases thereafter. The equimolar ratio of AChRs and the 43K protein found in the adult electric organ is established early in development. Furthermore, the AChR and 43K protein share a common postsynaptic localization in electrocytes following synapse formation. Aggregates of the AChR that form at the ventral pole of the oval-shaped electrocytes prior to innervation, however, show no detectable immunofluorescence staining with anti-43K monoclonal antibodies. Therefore, in some cases, aggregation of AChRs occurs without the 43K protein.
\end{abstract}

The neuromuscular postsynaptic membrane is highly specialized in the distribution of 2 ion channels: the acetylcholine receptor (AChR) (Fertuck and Salpeter, 1974) and the voltageactivated sodium channel (Beam et al., 1985). Proteins of the extracellular basal lamina and the postsynaptic cytoskeleton (Sanes, 1982; Bloch and Hall, 1983; Daniels et al., 1984; Froehner, 1984, 1986; Walker et al., 1985; Sealock et al., 1986; Froehner et al., 1987; Richardson et al., 1987; Woodruff et al., 1987) are thought to play a structural role at the synapse and may be involved in maintaining high concentrations of the AChR at the synapse.

Several identified cytoskeletal proteins are concentrated at the neuromuscular postsynaptic membrane (Hall et al., 1981; Burden, 1982; Bloch and Hall, 1983; Bloch, 1986; Sealock et al., 1986). In addition, studies of the Torpedo electrocyte synapse

\footnotetext{
Received Mar. 12, 1990; revised May 24, 1990; accepted June 18, 1990.

This work was supported by NIH Research Grant NS14871 and by the Muscular Dystrophy Association. Dr. Froehner is an Established Investigator of the American Heart Association.

Correspondence should be addressed to Dr. Stanley C. Froehner at the above address.

a Present address: Laboratory of Cellular and Molecular Biology, National Cancer Institute, National Institutes of Health, Bethesda, MD 20892.

"Present address: Max-Planck-Institut fur medizinische Forschung, Jahnstrasse 29, D 6900 Heidelberg, FRG.

Copyright (C) 1990 Society for Neuroscience $0270-6474 / 90 / 103460-08 \$ 03.00 / 0$
}

have led to the identification of other postsynaptic proteins of molecular weight 43,000 (43K protein); 58,000 (58K protein); 87,000 ( $87 \mathrm{~K}$ protein); and $280,000-300,000 \mathrm{Da}$ (300K protein) (Froehner, 1984; Froehner et al., 1987; Woodruff et al., 1987; Carr et al., 1989). Interest in these components has arisen primarily because their removal by alkaline extraction is accompanied by a significant increase in the mobility of the AChR in Torpedo (Barrantes et al., 1980; Lo et al., 1980; Cartaud et al., 1981; Rousselet et al., 1982) and rat (Bloch and Froehner, 1986) postsynaptic membranes. Thus, considerable effort has been devoted to the study of the roles of these proteins in synapse structure and function.

The $43 \mathrm{~K}$ protein is the most thoroughly characterized. In adult electric organs and differentiated myotubes, the $43 \mathrm{~K}$ protein and the $\mathrm{AChR}$ are present in approximately equimolar concentrations (LaRochelle and Froehner, 1986, 1987). In variant muscle cell lines, the concentrations of the $\operatorname{AChR} \beta$ subunit and the $43 \mathrm{~K}$ protein are reduced in parallel (LaRochelle et al., 1989). The AChR and $43 \mathrm{~K}$ protein exhibit a very similar, if not identical, distribution in the postsynaptic membrane of Torpedo electrocytes (Sealock et al., 1984; Bridgman et al., 1989) and vertebrate neuromuscular junctions (Froehner et al. 1981; Froehner, 1984) and at AChR clusters on muscle myotubes in culture (Burden, 1985; Peng and Froehner, 1985; Bloch and Froehner, 1986). In purified Torpedo membranes, the $43 \mathrm{~K}$ protein and the AChR can be chemically cross-linked through the $\beta$ subunit, suggesting a close association between the $43 \mathrm{~K}$ protein and the AChR (Burden et al., 1983). In addition, there is evidence that actin can associate with the $43 \mathrm{~K}$ protein in vitro (Walker et al., 1984). The amino acid sequences of the Torpedo (Carr et al., 1987; Frail et al., 1987), mouse (Frail et al., 1988; Froehner, 1989), and Xenopus (Baldwin et al., 1988) 43K proteins have been determined. Except for a cysteinc-rich sequence similar to the regulatory domain of protein kinase $\mathrm{C}$ that may be involved in membrane interactions (Froehner, 1989), extensive homology with other known proteins was not evident. Recent studies have demonstrated a direct role for the $43 \mathrm{~K}$ protein in AChR clustering. AChRs expressed in Xenopus oocytes by injection of RNA-encoding receptor subunits are diffusely distributed on the oocyte surface. Coexpression with the $43 \mathrm{~K}$ protein causes the AChR to form small clusters (Froehner et al., 1990). These results suggest that the $43 \mathrm{~K}$ protein plays a key role in AChR clustering during synaptogenesis.

The $58 \mathrm{~K}, 87 \mathrm{~K}$, and $300 \mathrm{~K}$ proteins are also concentrated at AChR-rich synaptic sites (Froehner et al., 1987; Woodruff et al., 1987; Carr et al., 1989). In contrast to the $43 \mathrm{~K}$ protein, 
however, these 3 proteins are also found in significant concentrations on the extrasynaptic membrane of skeletal muscle. The function of these proteins is not known.

One approach to determining the synaptic function of these proteins is to compare their expression at the synapse with alterations in synaptic events, especially those involving changes in the properties of the AChR. The electromotor system of Torpedo marmorata provides an ideal source for analysis of differentiation-dependent changes, as well as changes that occur during synapse formation. Because of the long gestation period, which can be as long as $1 \mathrm{yr}$, morphological (Fox and Richardson, 1978, 1979) and functional (Krenz et al., 1980) events can be correlated precisely with changes in synapse-associated proteins (Witzemann and Boustead, 1982; Witzemann et al., 1983a,b). In this report, we have used Torpedo electric tissue at various stages of development to determine when the $43 \mathrm{~K}$ and $58 \mathrm{~K}$ proteins are expressed. The results show that both proteins are present at the earliest stages of synapse formation and increase in concentration in parallel with the AChR. Prior to synaptogenesis, however, the distributions of AChRs and the $43 \mathrm{~K}$ protein may differ.

\section{Materials and Methods}

Materials. Torpedo marmorata were obtained from the Institute de Biologie Marine, Arcachon, France. Embryos were staged according to their body length (in $\mathrm{mm}$ ). Avidin-alkaline phosphatase was obtained from Cappel Laboratories, Cochranville, PA. Sulfosuccinimidobiotin was purchased from Pierce Chemical Co., Rockford, IL. Microtiter plates (Falcon 3912 Microtest III Flexible plate, 96 wells) were obtained from Becton Dickinson Labware, Oxnard, CA. $\alpha$-Bungarotoxin was obtained from Boehringer, Mannheim, FRG and labeled with rhodamine as described by Ravdin and Axelrod (1977). Fluorescein isothiocyanate (FITC)-conjugated anti-mouse antibodies were obtained from Miles Scientific, Munich, FRG, and FITC-labeled phalloidin was from Molecular Probes, Junction City, OR.

Monoclonal antibodies. The production, characterization, and purification of monoclonal antibodies (mabs) to the Torpedo AChR (Froehner et al., 1983), 43K protein (Froehner, 1984), and 58K protein (Froehner et al., 1987) have been described. Anti-actin mab was purchased from Amersham. Biotinylated derivatives of mabs were prepared according to Bayer and Wilchek (1974) with the modifications of LaRochelle and Froehner (1986).

Preparation and solubilization of proteins for immunoblotting and 2-site assay. The electric organ from Torpedo marmorata embryonic stages $44,57,68,85,95,111$, and $120 \mathrm{~mm}$ and from adults was frozen in liquid nitrogen after dissection and stored at $-70^{\circ} \mathrm{C}$. Approximately $270-600 \mathrm{mg}$ of each tissue was partially thawed, minced, and homogenized at $135 \mathrm{mg} / \mathrm{ml}$ (tissue wet weight) with a glass-teflon homogenizer in 10 mM sodium phosphate buffer ( $\mathrm{pH}, 7.4), 5$ mM EDTA, 5 mM EGTA, $0.02 \%$ sodium azide, $10 \mathrm{U} / \mathrm{ml}$ aprotinin, $5 \mathrm{mg} / \mathrm{ml}$ pepstatin, $5 \mathrm{mg} / \mathrm{ml}$ leupeptin, $1.0 \mathrm{mg} / \mathrm{ml}$ iodoacetamide, and $2.5 \mathrm{mg} / \mathrm{ml}$ phenylmethylsulfonyl flouride (homogenization buffer). Tissue homogenates were stored at $-70^{\circ} \mathrm{C}$ in $500-\mu \mathrm{l}$ aliquots. The protein concentrations ranged from 2.1 to $2.9 \mathrm{mg} / \mathrm{ml}$, as determined by the method of Lowry et al. (1951).

For solubilization, $500 \mu \mathrm{l}$ of the homogenate was made $1.1 \%$ in Triton $\mathrm{X}-100$ and incubated on ice for $30 \mathrm{~min}$. The sample was then centrifuged for $30 \mathrm{~min}$ at $27,000 \times g$ and $300 \mu \mathrm{l}$ of the supernatant was diluted to $1 \%$ in BSA by the addition of $1 /$, vol of a $100 \mathrm{mg} / \mathrm{ml}$ solution of BSA. This sample was used at appropriate dilutions in the 2-site assay. (Immunoblotting demonstrated that greater than $95 \%$ of the AChR, $43 \mathrm{~K}$ protein, and $58 \mathrm{~K}$ protein were solubilized with Triton X-100 under these conditions.) For SDS gel electrophoresis, an aliquot of the Triton extract was diluted to $1 \mathrm{mM}$ in $N$-ethylmaleimide, and an equal volume of $2 \times$ sample electrophoresis buffer containing $50 \mathrm{~mm}$ dithiothreitol was added. Both gel electrophoresis in SDS and immunoblotting were performed as previously described (Froehner et al., 1983; Froehner, 1984) using the mab IgG at a concentration of $50 \mathrm{~nm}$ or ascites fluid at a 1/100 dilution. For immunoblotting of actin, tissue homogenates were solubilized directly with an equal volume of double-strength sample electrophoresis buffer.

Two-site assay for $A C h R$ and $43 \mathrm{~K}$ protein. The preparation of $43 \mathrm{~K}$ protein and AChR standards and the 2-site assay procedure are described in detail in LaRochelle and Froehner (1986). Briefly, wells of a microtiter plate were coated with $\mathrm{mab} \mathrm{IgG}$, then incubated with BSA to block nonspecific binding. Tissue proteins dissolved in Triton X-100 were added, and the antigen was allowed to bind to the mab. After removal of unbound proteins, a second mab derivatized with biotin directed against a spatially distinct epitope was added to the well. Finally, the amount of bound biotinylated mab was determined after incubation with avidin-alkaline phosphatase and determination of enzyme activity. Standard curves for each protein were done in each experiment.

Immunohistochemical procedure. Cryostat sections $(10-\mu \mathrm{m}$ thickness) were prepared from fresh tissue fixed for $3 \mathrm{hr}$ at $4^{\circ} \mathrm{C}$ with $4 \%$ paraformaldehyde in $0.4 \mathrm{~m}$ sodium cacodylate buffer ( $\mathrm{pH}, 7.4$ ). Formaldehyde-fixed material was cryoprotected by impregnating the blocks in $20 \%$ sucrose in $0.4 \mathrm{M}$ sodium cacodylate buffer $(\mathrm{pH}, 7.4)$ at $4^{\circ} \mathrm{C}$ after rinsing out the formaldehyde. Frozen sections prepared from formaldchydc-fixed tissue were transferred to a small drop of cold water on an albumin-glycerol-coated slide and allowed to spread. Once the sections had flattened, the excess water was removed, and the sections were allowed to dry for $2 \mathrm{~d}$ at $37^{\circ} \mathrm{C}$ before use. All tissue sections were preincubated in Tris-HCl-buffered saline (TBS) containing 3\% BSA (TBSA) for $1 \mathrm{hr}$ to block nonspecific protein-binding sites prior to a 2-hr incubation in the primary antibody. All antibodies were diluted in TBSA. Mab $1098 \mathrm{C}$ was used at a dilution of $1 / 500$. After incubation, the tissue sections were washed with TBS and incubated with a mixture of FITC-conjugated anti-mouse antibodies (1/40 dilution) and rhodamine-labeled $\alpha$-bungarotoxin $(0.1 \mu \mathrm{g} / \mathrm{ml})$ in TBSA for $1 \mathrm{hr}$. After a thorough wash, the sections were mounted in Tris/glycerol $(1: 9 ; \mathrm{pH}, 8)$. Tissue sections were examined with a Zeiss Photomicroscope III equipped for epifluorescence. Photomicrographs were made on Kodak TriX film rated 1600 ASA.

\section{Results}

The Torpedo electric organ develops from cylindrical, vertically oriented myotubes (20-30 mm embryos). At this early stage of the electrogenic phase of development, AChRs are evenly and diffusely distributed over the myotube surface. On morphological differentiation, these cells round up and become horizontally flattened, disk-shaped electrocytes (30-55-mm embryos). A basal lamina forms, and the AChRs become localized on the ventral membrane without direct neuronal contacts. The "synaptogenic" phase ( $55-\mathrm{mm}$ cmbryos to birth) is characterized by axons invading the stacks of electrocytes forming synaptic contacts on the ventral side of each cell (Fox and Richardson, 1978, 1979).

Torpedo electric organs from several stages of the electrogenic phase of development, ranging from 44-mm embryos to adults, were analyzed by immunoblotting to compare the expression of the AChR with 3 other proteins found in postsynaptic membrane preparations: the $43 \mathrm{~K}$ protein, the $58 \mathrm{~K}$ protein, and actin (Figs. 1, 2). Equivalent amounts of protein from each embryonic stage were analyzed with $2 \mathrm{AChR}$ mabs directed to different subunits (mab 139 recognizes the $\alpha$ subunit; mab 88B binds both the $\gamma$ and $\delta$ subunits), $243 \mathrm{~K}$ mabs (mab 1234 and mab 1579) that recognize different epitopes, and single mabs for either $58 \mathrm{~K}$ protein (mab 1351) or actin. In agreement with previous results (Witzemann et al., 1983a,b), AChRs were detectable in electric organs as soon as motor neurons form contacts with electrocytes at the 55-mm stage (Fox and Richardson, 1979) and thereafter increased dramatically, reaching near-adult levels by the $111-\mathrm{mm}$ stage. The $\mathrm{AChR} \beta$ subunit expression was similar to that of $\alpha, \gamma$, and $\delta$ (data not shown). Expression of the $43 \mathrm{~K}$ protein and the $58 \mathrm{~K}$ protein followed a time course similar to that of $\mathrm{AChRs}$, though the increase in the $58 \mathrm{~K}$ protein did not appear to be as large as the other 2 proteins. In contrast, 
Figure 1. Immunoblot analysis of postsynaptic membrane proteins during electrocyte differentiation. Electric organ proteins from embryonic stages $57 \mathrm{~mm}$ (lane 1), $68 \mathrm{~mm}$ (lane 2), 85 $\mathrm{mm}$ (lane 3), $95 \mathrm{~mm}$ (lane 4), $111 \mathrm{~mm}$ (lane 5), and adult (lane 6) were subjected to SDS gel electrophoresis and either stained with Coomassie blue $(A)$ or immunoblotted with monoclonal the AChR $\gamma$ and $\delta$ subunit $(C), 43 \mathrm{~K}$ protein (mab $1234, D), 43 \mathrm{~K}$ protein $(G)$, or control mab MOPC $21(H)$. Positions of the $\alpha, \gamma$, and $\delta$ AChR subunits and the $43 \mathrm{~K}$ and $58 \mathrm{~K}$ proteins are indicated. antibodies to the AChR $\alpha$ subunit (B), (mab $1579, E), 58 \mathrm{~K}$ protein $(F)$, actin
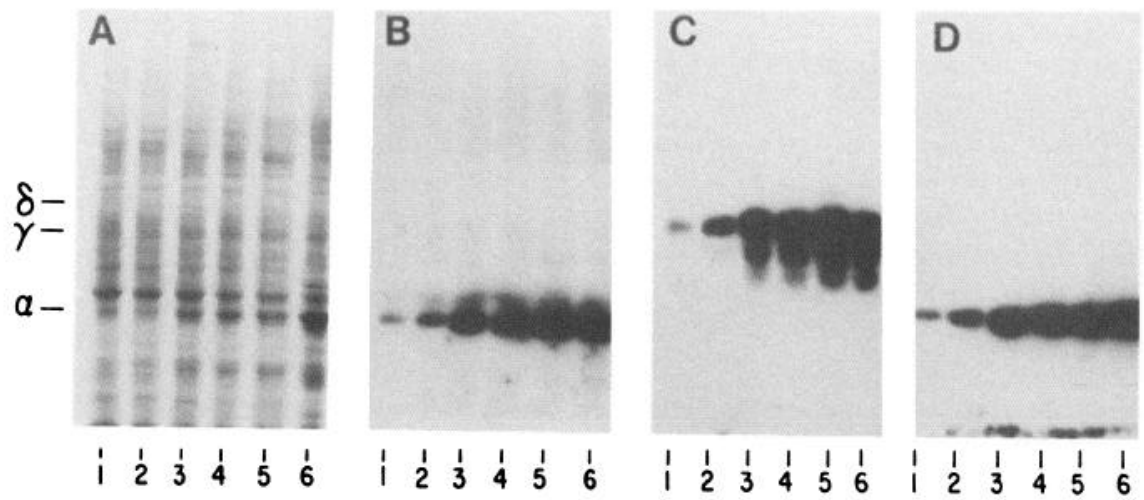

$-43 k$
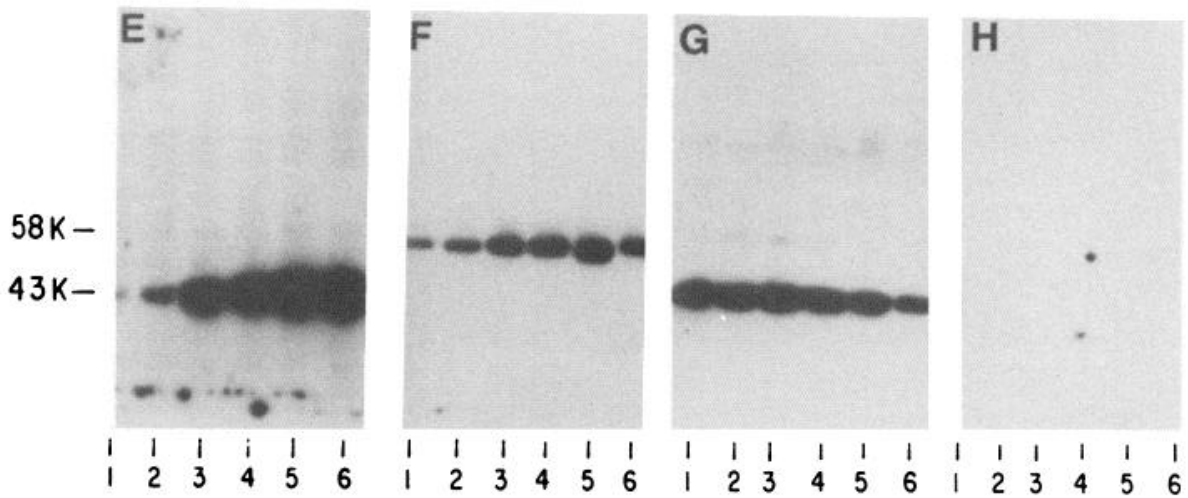

actin concentrations were highest at the early stages and decreased to less than $1 / 2$ that value by adulthood.

The expression of synaptic proteins in electric organs prior to $(44 \mathrm{~mm})$ and after $(58 \mathrm{~mm}$ and $62 \mathrm{~mm})$ the formation of synaptic contacts were compared in a separate experiment (Fig. 2 ). The $A C h R, 43 \mathrm{~K}$ protein, and $58 \mathrm{~K}$ protein are all present in 44-mm embryos but then increase dramatically by the $58-\mathrm{mm}$

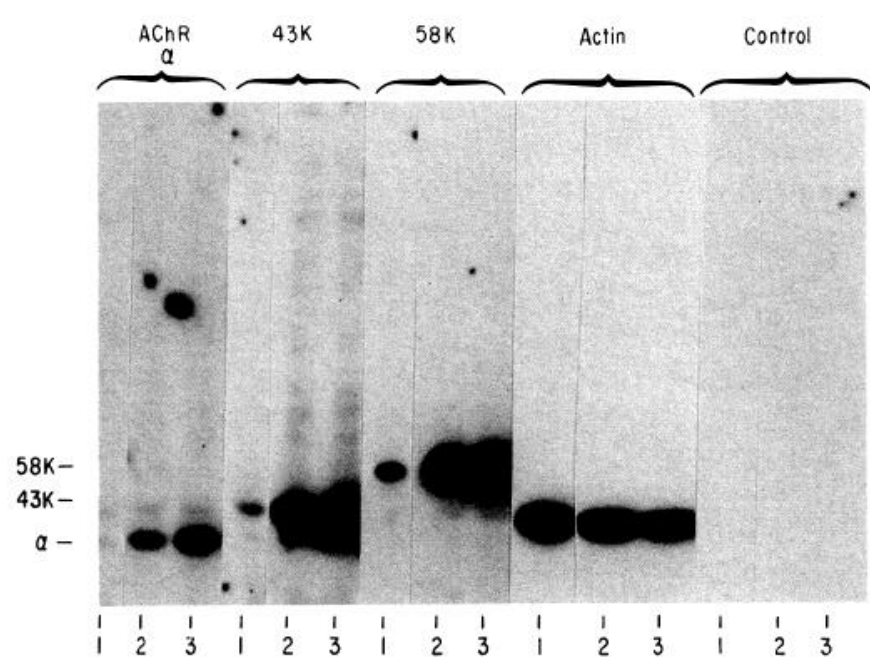

Figure 2. Immunoblot analysis of postsynaptic membrane proteins during early electrocyte differentiation. Electric organ proteins from embryonic stages $44 \mathrm{~mm}$ (lane 1), $58 \mathrm{~mm}$ (lane 2), and $62 \mathrm{~mm}$ (lane 3 ) were immunoblotted with monoclonal antibodies to $\mathrm{AChR} \alpha$ subunit, $43 \mathrm{~K}$ protein (mab 1234), $58 \mathrm{~K}$ protein, actin, or control mab MOPC 21.

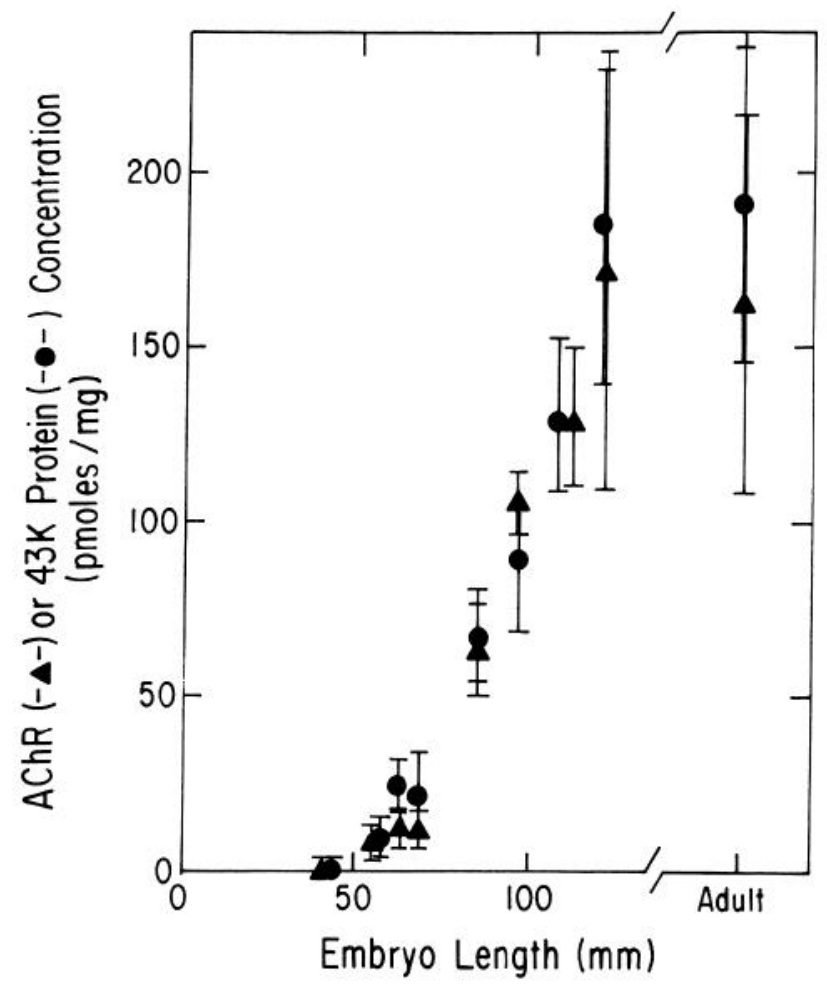

Figure 3. Coexpression of $43 \mathrm{~K}$ protein and $\mathrm{AChRs}$ during electrocyte differentiation. Amounts of both proteins were measured by the 2-site assay as described in Materials and Methods. For the 44-mm, 62-mm, and $120-\mathrm{mm}$ samples, error bars indicate the standard deviation from 2 experiments $(n=6)$. For the $57-\mathrm{mm}$ and $68-\mathrm{mm}$ samples, 5 separate measurements were performed $(n=15)$. Three measurements $(n=9)$ were performed on $85-\mathrm{mm}, 95-\mathrm{mm}$, and 111-mm samples. 

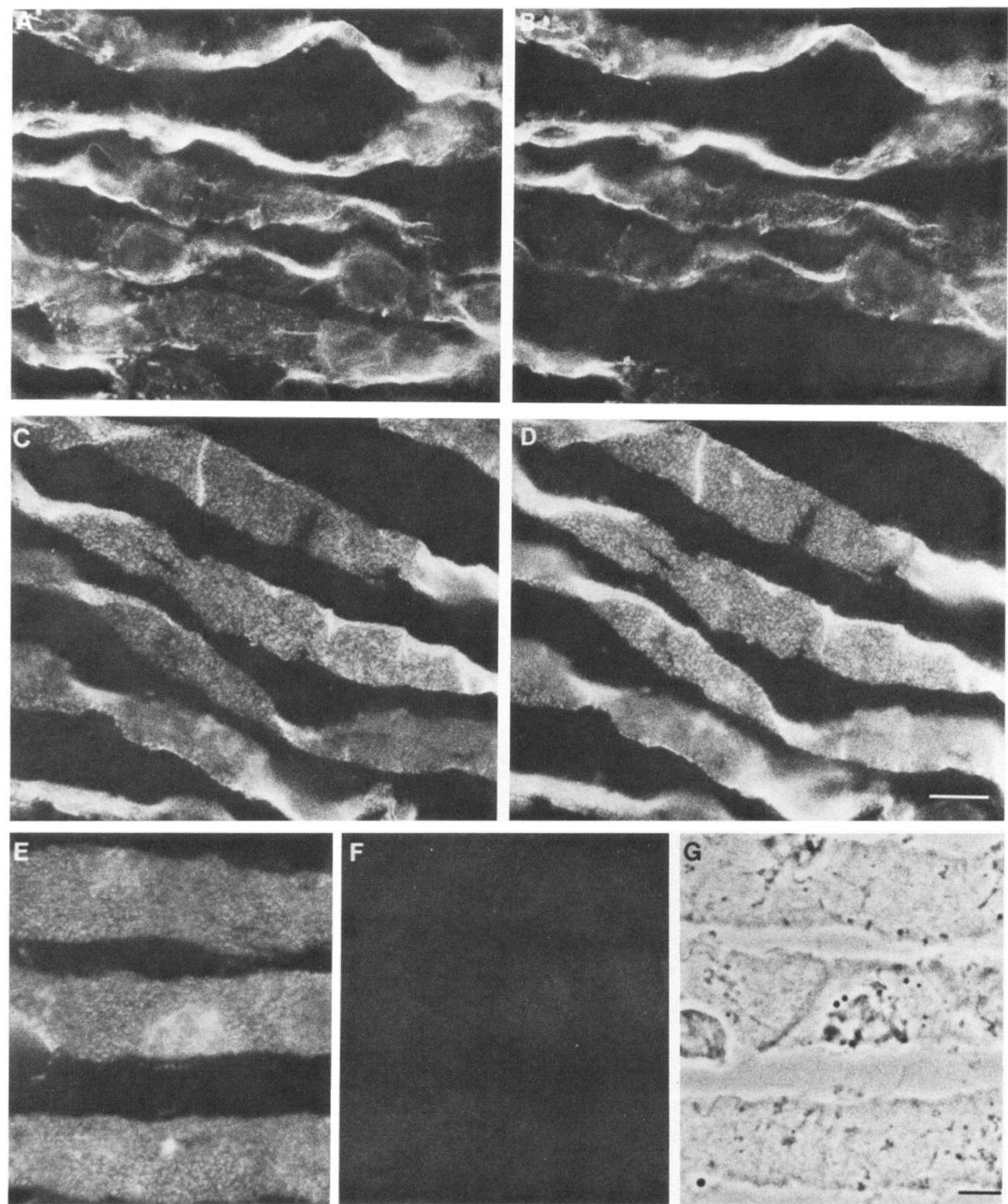

Figure 4. Immunofluorescence localization of $\mathrm{AChR}$ and $43 \mathrm{~K}$ protein in innervated electrocytes from embryonic Torpedo. Fixed sections of Torpedo embryos were incubated with rhodamine-labeled $\alpha$-bungarotoxin $(A, C, E)$ and anti-43K mab $1098 \mathrm{C}$ followed by fluorescein-conjugated anti-mouse $\operatorname{IgG}(B, D)$. $A$ and $B, 68-\mathrm{mm}$ embryo. $C-G, 93-\mathrm{mm}$ embryo. The section shown in $F$ was incubated with fluorescein anti-mouse IgG alone to demonstrate the specificity of mab labeling. A phase-contrast view is shown in $G$. Scale bar in $D, 10 \mu \mathrm{m} ;$ in $G, 5 \mu \mathrm{m}$. 

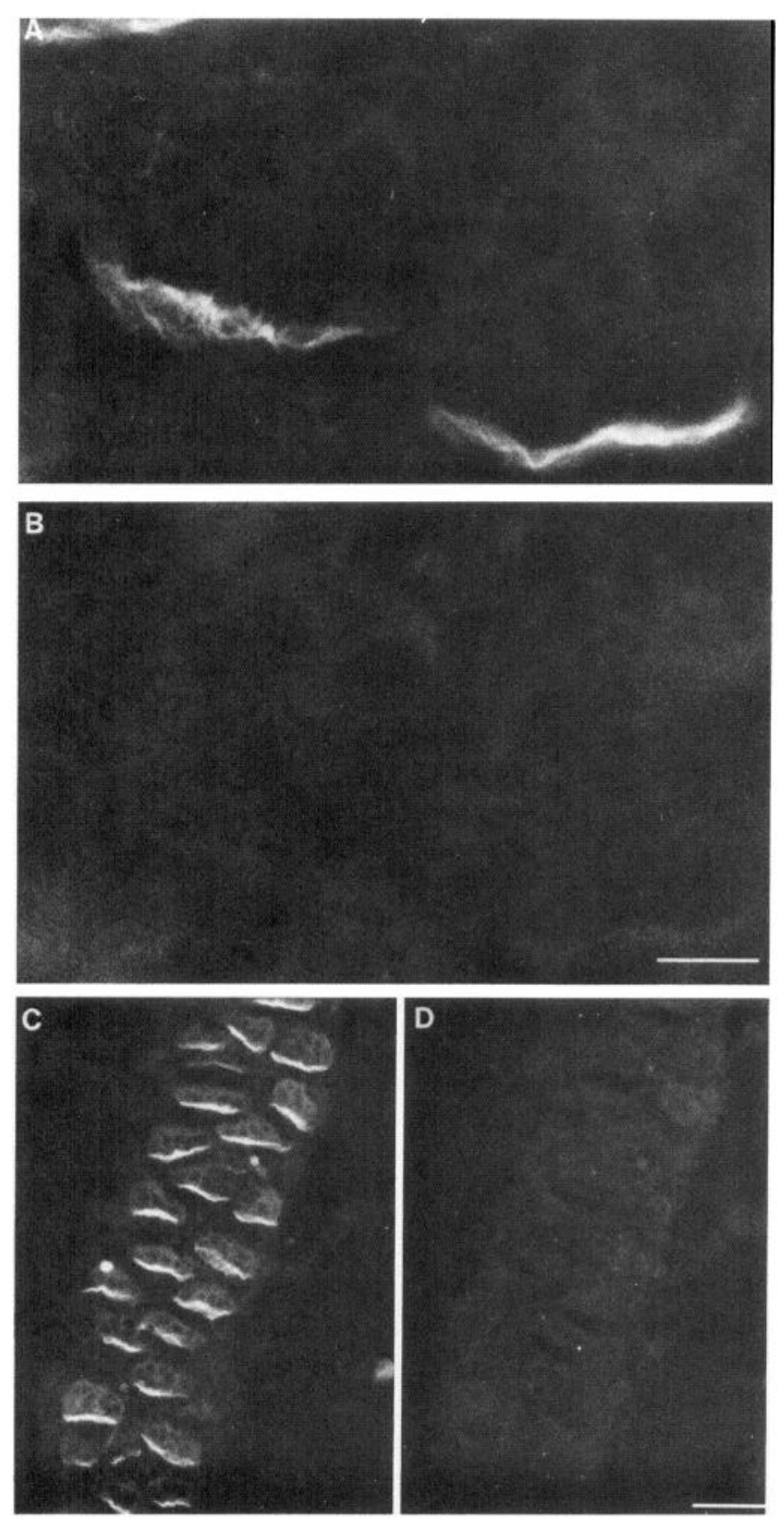

Figure 5. Immunofluorescence localization of $\mathrm{AChRs}$ and $43 \mathrm{~K}$ protein in electrocytes from embryonic Torpedo before innervation. Fixed sections of Torpedo embryos were incubated with rhodamine-labeled $\alpha$-bungarotoxin $(A, C)$ and anti-43K mab $1098 \mathrm{C}$ followed by fluorescein-conjugated anti-mouse IgG $(B, D) . A$ and $B, 44-\mathrm{mm}$ embryo. $C$ and $D, 52-\mathrm{mm}$ embryo. Scale bar in $B, 10 \mu \mathrm{m}$; in $D, 50 \mu \mathrm{m}$. At the lower magnification, the formation of stacks of flattened electrocytes can be seen. Receptors are clustered in the ventral membrane, which will be contacted by the motor neuron at about the $55-\mathrm{mm}$ embryo stage. The $43 \mathrm{~K}$ protein is not selectively associated with the ventral membrane at that stage of development.

stage. In contrast, actin concentrations are approximately the same at these 2 stages. Thus, as judged by these qualitative measurements, the $\mathrm{AChR}, 43 \mathrm{~K}$ protein, and $58 \mathrm{~K}$ protein are each present in electrocytes prior to innervation. The large increase seen after innervation may indicate that the expression of these proteins is affected by innervation. As expected, the transition from a muscle-like cell early in development to an electrocyte is accompanied by a decrease in actin concentrations.

In adult electric organ, the $\mathrm{AChR}$ and $43 \mathrm{~K}$ protein are present in approximately equimolar amounts (LaRochelle and Froehner, 1986). To determine when during development this relationship is established, we used a quantitative 2-site immunological assay to measure concentrations of these 2 proteins in embryos of different ages. As shown in Figure 3, the AChR and $43 \mathrm{~K}$ protein concentrations in the electric organ are closely matched throughout development, beginning with the earliest stages measured. Prior to synaptogenesis (44-mm stage), the concentrations of both proteins are very low and are difficult to measure with great accuracy using the immunochemical assay. However, the values obtained $(0.43 \pm 0.15 \mathrm{pmol} / \mathrm{mg}$ for $\mathrm{AChR}$, $0.24 \pm 0.10 \mathrm{pmol} / \mathrm{mg}$ for $43 \mathrm{~K}$ protein) are within the same range, suggesting that the approximate stoichiometric relationship between the $43 \mathrm{~K}$ protein and the $\mathrm{AChR}$ may be established prior to synaptogenesis.

The AChR and the $43 \mathrm{~K}$ protein share a common distribution in the adult electric organ. Both are restricted to the innervated membrane (Froehner, 1984) and, at the ultrastructural level (Sealock et al., 1984), are codistributed in the postsynaptic membrane on the crests of the folds. To determine when during development this physical association is attained, the distributions of the AChR and the $43 \mathrm{~K}$ protein in electric organs from several stages of development were compared by immunofluorescence microscopy. Fixed cryostat sections were incubated first with mabs to the $43 \mathrm{~K}$ protein, then with a mixture of fluorescein-conjugated anti-mouse IgG and rhodamine-labeled $\alpha$-bungarotoxin (to label the receptors). In both $68-\mathrm{mm}$ and 93-mm embryos, the ventral membrane, seen in a flattened, en face view (Fiedler et al., 1986), was stained specifically for the $43 \mathrm{~K}$ protein (Fig. 4). Ventral electrocyte membranes in 93mm embryos displayed an ordered structure of AChRs, a densepacked distribution of brightly stained spots. The staining of the $43 \mathrm{~K}$ protein closely matched this distribution of AChRs. The receptor distribution in electrocytes from $68-\mathrm{mm}$ embryos was much more diffuse. $43 \mathrm{~K}$-protein staining showed a similar diffuse distribution. Higher-density spots of receptors were infrequent but, when they occurred, also showed corresponding staining with anti-43K mabs. This change from a diffuse to an ordered distribution of these 2 proteins during synaptogenic development supports previous findings (Witzemann et al., 1983a), indicating changes in the structural organization of the developing postsynaptic membrane.

In differentiating electrocytes from 40-55-mm embryos, which are not yet innervated, a region of high AChR density forms on the ventral surface of each oval-shaped cell, as shown by autoradiography (Witzemann et al., 1983b) or by rhodamine $\alpha$ bungarotoxin staining (Fig. 5). The mechanism leading to the restriction of AChRs to this region of the cell is not known, but could be influenced by components of either the extracellular matrix or the cytoskeleton. We detected no staining of this membrane site with anti-43K antibodies in $48-\mathrm{mm}$ or $52-\mathrm{mm}$ embryos (Fig. 5), even though these cells clearly express the $43 \mathrm{~K}$ protein, as demonstrated by both Western blotting and the 2-site assay.

The distribution and structural organization of actin changes in a characteristic manner during electric organ development. In 48-mm embryos, F-actin bundles, revealed by staining with 

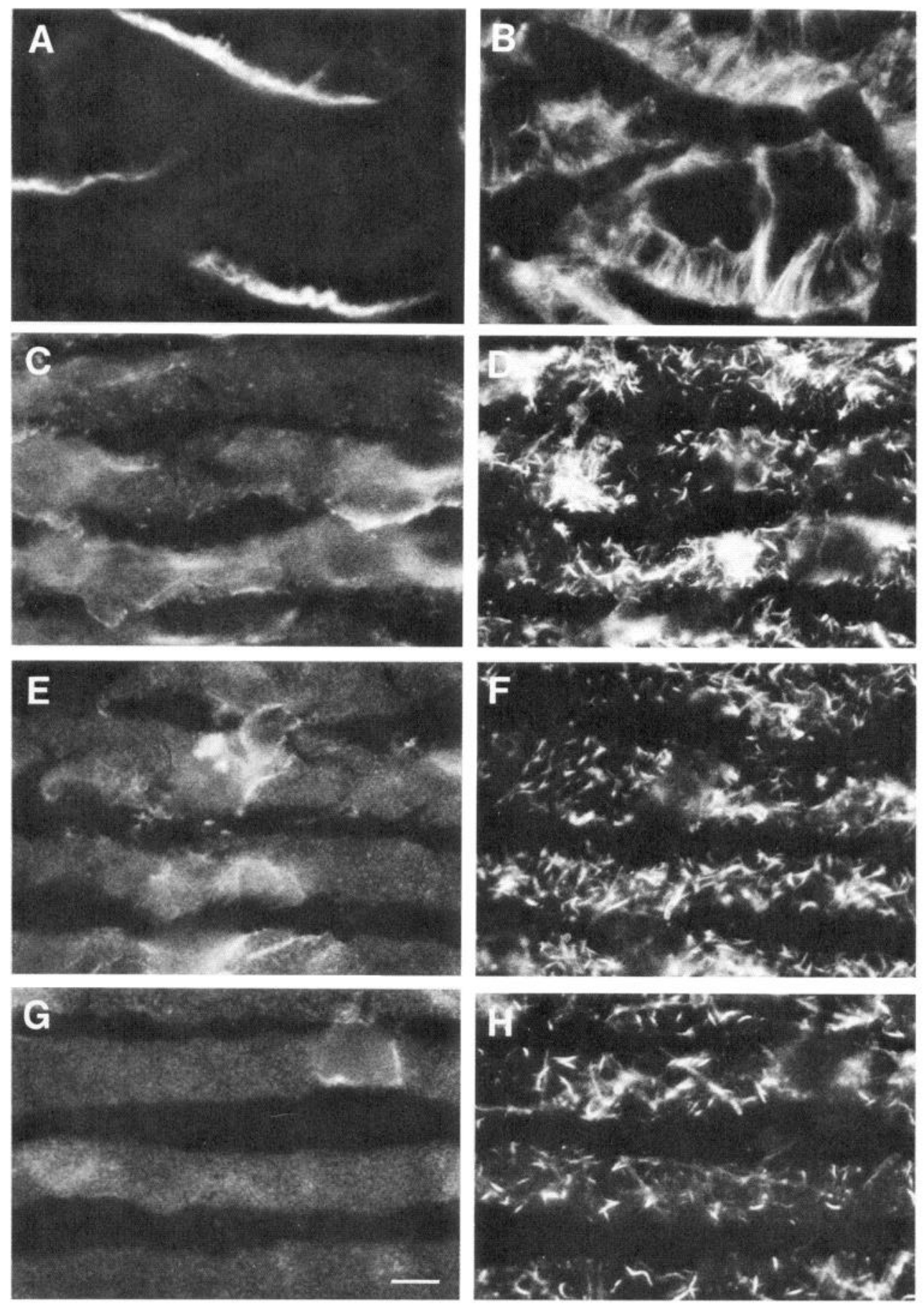

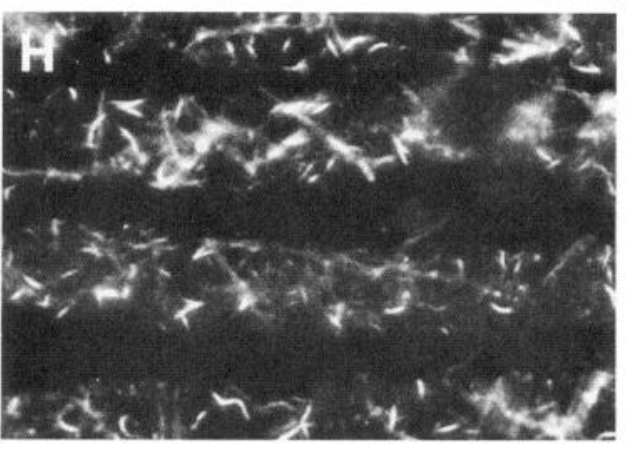

Figure 6. Immunofluorescence localization of F-actin in electrocytes from embryonic Torpedo. AChR distribution was determined by incubation of sections with rhodamine-labeled $\alpha$-bungarotoxin $(A, C, E, G)$. Fluoresceinlabeled phalloidin was used to localize the F-actin distribution $(B, D, F, H) . A$ and $B, 48$-mm embryo. $C$ and $D, 68$ mm embryo. $E$ and $F, 81-\mathrm{mm}$ embryo. $G$ and $H, 93-m m$ embryo. Scale bar in $G, 10 \mu \mathrm{m}$. fluorescein-conjugated phalloidin, extend from the plane of the nuclei and terminate in the AChR-containing ventral membrane (Fig. 6). At the level of resolution provided by fluorescence microscopy, no specific colocalization with AChRs is evident. After the formation of synaptic contacts, F-actin is still present, but is not associated with any obvious structural meshwork within the cell. The content of F-actin decreases during late embryonic stages and, in the adult electric organ, appears to be mainly associated with the presynaptic terminal (Walker et al., 1985).

\section{Discussion}

The purpose of these studies was to determine when 2 postsynaptic cytoskeletal elements, the $43 \mathrm{~K}$ and $58 \mathrm{~K}$ proteins, are first expressed during Torpedo electrocyte differentiation and synaptogenesis and to compare the time course of their expression with that of the $\mathrm{AChR}$. The $43 \mathrm{~K}$ and $58 \mathrm{~K}$ proteins, as well as the $\mathrm{AChR}$, are present in electrocytes prior to innervation. After the formation of synaptic contacts, the amounts of both proteins rise in concert with the $\mathrm{AChR}$. The approximate equimolar ratio 
of the $43 \mathrm{~K}$ protein and the AChR is established early during electrocyte differentiation and is maintained as the amounts of both proteins increase almost 200 -fold.

The relationship between AChR and 43K protein expression has also been studied in mammalian skeletal muscle cells. Using a 2-site assay similar to the one described here, LaRochelle and Froehner (1987) detected no $43 \mathrm{~K}$ protein in myoblasts, but found a close correspondence between AChR and 43K protein levels during myotube formation and differentiation. In contrast, Frail et al. (1989) found similar rates of synthesis of the $43 \mathrm{~K}$ protein, measured by metabolic labeling, in both myoblasts and myotubes. This discrepancy could be explained if the steadystate levels of the $43 \mathrm{~K}$ protein differ in myoblasts and myotubes because the degradation rate changes with differentiation. Results with variants of the $\mathrm{C} 2$ muscle cell line that fail to express AChR subunit indicate that the amount of $43 \mathrm{~K}$ protein is coregulated with the $\mathrm{AChR}$ concentration, possibly by stabilization of the $43 \mathrm{~K}$ protein upon association with the receptor (LaRochelle et al., 1989). Although no difference in degradation rate for $43 \mathrm{~K}$ protein was found in myoblasts and myotubes (Frail et al., 1989), the labeling protocol may not have detected relatively stable proteins. The results reported here demonstrate a close correlation between $\mathrm{AChR}$ and $43 \mathrm{~K}$ protein concentrations after synaptogenesis and further support the hypothesis that these 2 proteins are coregulated at some step subsequent to translation.

The distributions of the $\mathrm{AChR}$ and the $43 \mathrm{~K}$ protein have been compared in the adult Torpedo electric organ (Sealock et al., 1984), at the mammalian neuromuscular junction (Froehner, 1984; Froehner et al., 1981), and in clusters of receptors that form on mouse (LaRochelle et al., 1989), rat (Bloch and Froehner, 1986), chick (Carr et al., 1989), and Xenopus (Burden, 1985; Peng and Froehner, 1985) muscle cells in culture. In all cases, the distributions of the 2 components were quite similar, if not indistinguishable. These findings were consistent with the view that the $43 \mathrm{~K}$ protein is associated directly with the AChR and anchors receptors at synapses and in clusters on aneural muscle cultures. The recent demonstration that coexpression of the AChR and the 43K protein in Xenopus oocytes causes receptor clustering (Froehner et al., 1990) strongly supports this view. Hence, the observation that, in the early stages of electrocyte differentiation, accumulations of AChRs at one pole of the ovalshaped cell fail to stain for the $43 \mathrm{~K}$ protein was unexpected. Similar results have also been reported by Kordeli et al. (1989). These findings suggest that, in this case, the $43 \mathrm{~K}$ protein is not required for AChR clustering. It is difficult, however, to eliminate the possibility that the $43 \mathrm{~K}$ protein is present but at a concentration below that required for detection by immunofluorescence. Detection of similar amounts of the AChR could be explained by the high affinity of $\alpha$-bungarotoxin binding, which may be 100-1000-fold higher than mab binding to the $43 \mathrm{~K}$ protein.

The mechanisms responsible for $\mathrm{AChR}$ accumulation at the ventral pole of differentiating electrocytes prior to neuronal contact are not known, but appear to be different from those responsible for $\mathrm{AChR}$ anchoring during the synaptogenic phase. Kordeli et al. (1989) have suggested that components of the basement membrane, such as laminin, may play a role in AChR clustering at this early stage. The relationship of these clusters that form prior to innervation to those at mature synapses is unknown. Aggregates on uninnervated electrocytes may represent unusual features of the developing electrocyte that result from diffusion barriers or other specializations that are not relevant to the process of synaptogenesis.

\section{References}

Baldwin TJ, Theirot JA, Yoshihara CM, Burden SJ (1988) Regulation of the transcript encoding the 43 kilodalton subsynaptic protein during development and after denervation. Development 104:557-564.

Barrantes FJ, Neugebauer D-C, Zingsheim HP (1980) Peptide extraction by alkaline treatment is accompanied by rearrangement of the membrane-bound acetylcholine receptor from Torpedo marmorata. FEBS Lett 112:73-78.

Bayer EA, Wilchek M (1974) Insolubilized biotin for the purification of avidin. Meth Enzymol 34:265-267.

Beam KG, Caldwell JH, Campbell JT (1985) Na channels in skeletal muscle concentrated near the neuromuscular junction. Nature 313: 588-590.

Bloch RJ (1986) Actin at receptor-rich domains of isolated acetylcholine receptor clusters. J Cell Biol 102:1447-1458.

Bloch RJ, Froehner SC (1986) The relationship of the postsynaptic $43 \mathrm{~K}$ protein to acetylcholine receptors in receptor clusters isolated from cultured rat myotubes. J Cell Biol 104:645-654.

Bloch RJ, Hall ZW (1983) Cytoskeletal components of the vertebrate neuromuscular junction: vinculin, alpha-actinin and filamin. J Cell Biol 97:217-223.

Bridgman PC, Carr C, Pedersen SE, Cohen JB (1989) Visualization of the cytoplasmic surface of Torpedo postsynaptic membrane by freeze-etch and immunoelectron microscopy. J Cell Biol 105:18291846.

Burden SJ (1982) Identification of an intracellular postsynaptic antigen at the frog neuromuscular junction. J Cell Biol 94:521-530.

Burden SJ (1985) The subsynaptic $43 \mathrm{kDa}$ protein is concentrated at developing nerve-muscle synapses in vitro. Proc Natl Acad Sci USA 82:8270-8273.

Burden SJ, DePalma RL, Gottesman GS (1983) Crosslinking of proteins in acetylcholine receptor-rich membranes: association between the beta-subunit and the 43kD subsynaptic protein. Cell 35:687-692.

Carr C, McCourt D, Cohen JB (1987) The 43kDa protein of Torpedo nicotinic postsynaptic membranes: purification and determination of primary sequence. Biochemistry 26:7090-7102.

Carr C, Fischbach GD, Cohen JB (1989) A novel $M_{\mathrm{r}} 87,000$ protein associated with acetylcholine receptors in Torpedo electric organ and vertebrate skeletal muscle. J Cell Biol 109:1753-1764.

Cartaud J, Sobel A, Rousselet A, Devaux PF, Changeux JP (1981) Consequences of alkaline treatment for the ultrastructure of the acetylcholine-receptor rich membranes from Torpedo marmorata electric organ. J Cell Biol 90:418-426.

Daniels MP, Vigny M, Sonderegger P, Bauer HC, Vogel Z (1984) Association of laminin and other basement membrane components with regions of high acetylcholine receptor density on cultured myotubes. Int J Dev Neurosci 2:87-99.

Fertuck HC, Salpeter MM (1974) Localization of acetylcholine receptor by ${ }^{125}$ I-labeled alpha bungarotoxin binding at mouse motor endplates. Proc Natl Acad Sci USA 71:1376-1378.

Fiedler W, Borroni E, Ferretti P (1986) An immunohistochemical study of synaptogenesis in the electric organ of Torpedo marmorata by use of antisera to vesicular and presynaptic plasma membrane components. Cell Tissue Res 246:439-446.

Fox GO, Richardson GP (1978) The development morphology of Torpedo marmorata: electric organ-myogenic phase. J Comp Neurol 179:677-698.

Fox GQ, Richardson GP (1979) The development morphology of Torpedo marmorata: electric organ-electrogenic phase. J Comp Neurol 185:293-316.

Frail DE, Mudd J, Shah V, Carr C, Cohen JB, Merlie JP (1987) cDNAs for the postsynaptic $M_{\mathrm{r}} 43,000$ protein of Torpedo electric organ encode two proteins with different carboxy termini. Proc Natl Acad Sci USA 84:6302-6306.

Frail DE, McLaughlin LL, Mudd J, Merlie JP (1988) Identification of the mouse muscle 43,000-dalton acetylcholine receptor-associated protein (RAPsyn) by cDNA cloning. J Biol Chem 263:15602-15607. Frail DE, Musil S, Buonanno A, Merlie JP (1989) Expression of RAPsyn (43K protein) and nicotinic acetylcholine receptor genes is not coordinately regulated in mouse muscle. Neuron 2:1077-1086.

Froehner SC (1984) Peripheral proteins of postsynaptic membranes 
from Torpedo electric organ identified with monoclonal antibodies. J Cell Biol 99:88-96.

Froehner SC (1986) The role of the postsynaptic cytoskeleton in AChR organization. Trends Neurosci 9:37-4l.

Froehner SC (1989) Expression of RNA transcripts for the postsynaptic $43 \mathrm{kDa}$ protein in innervated and denervated rat skeletal muscle. FEBS Lett 249:229-233.

Froehner SC, Gulbrandsen V, Hyman C, Jeng AY, Neubig RR, Cohen JB (1981) Immunofluorescence localization at the mammalian neuromuscular junction of the $M_{\mathrm{r}} 43,000$ protein of Torpedo postsynaptic membrane. Proc Natl Acad Sci USA 78:5230-5234.

Froehner SC, Douville K, Klink S, Culp WJ (1983) Monoclonal antibodies to cytoplasmic domains of the acetylcholine receptor. J Biol Chem 258:7112-7120.

Froehner SC, Luetje CW, Scotland PB, Patrick J (1990) The postsynaptic $43 \mathrm{~K}$ protein clusters muscle nicotinic acetylcholine receptors in Xenopus oocytes. Neuron, in press.

Froehner SC, Murnane AA, Tobler M, Peng HB, Sealock R (1987) A postsynaptic $M_{\mathrm{r}} 58,000(58 \mathrm{~K})$ protein concentrated at acetylcholine receptor-rich sites in Torpedo electroplaques and skeletal muscle. J Cell Biol 104:1633-1646.

Hall ZW, Lubit BW, Schwartz JH (1981) Cytoplasmic actin in postsynaptic structures at the neuromuscular junction. J Cell Biol 90:789792.

Kordeli E, Cartaud J, Nghiem H-O. Devillers-Thiery A, Changeux J-P (1989) Asynchronous assembly of the acetylcholine receptor and of the $43 \mathrm{kD}$ protein in the postsynaptic membrane of developing Torpedo marmorata electrocyte. J Cell Biol 108:127-139.

Krenz W-D, Tashiro T, Wachtler K, Whittaker VP, Witzemann V (1980) Aspects of the chemical embryology of the electromotor system of Torpedo marmorata with special reference to synaptogenesis. Neuroscience 5:617-624.

LaRochelle WJ, Froehner SC (1986) Determination of the tissue distributions and relative concentrations of the postsynaptic $43 \mathrm{kDa}$ protein and the acetylcholine receptor in Torpedo. J Biol Chem 261: 5270-5274.

LaRochelle WJ, Froehner SC (1987) Comparison of the postsynaptic $43 \mathrm{kDa}$ protein from muscle cells that differ in acetylcholine receptor A clustering activity. J Biol Chem 262:8190-8195.

LaRochelle WJ, Ralston E, Forsayeth JR, Froehner SC, Hall ZW (1989) Clusters of $43-\mathrm{kDa}$ protein are absent from genetic variants of $\mathrm{C} 2$ muscle cells with reduced acetylcholine receptor expression. Dev Biol 132:130-138.

Lo MMS, Garland PB, Lamprecht J, Barnard EA (1980) Rotational mobility of the membrane-bound acetylcholine receptor of Torpedo electric organ measured by phosphorescence depolarization. FEBS Lett 111:407-412.
Lowry O, Rosebrough N, Farr A, Randall RJ (1951) Protein measurement with the folin phenol reagent. J Biol Chem 193:265-275.

Peng HB, Froehner SC (1985) Association of the postsynaptic 43K protein with newly formed acetylcholine receptor clusters in cultured muscle cells. J Cell Biol 100:1698-1705

Ravdin P, Axelrod D (1977) Fluorescent tetramethyl rhodamine derivatives of alpha-bungarotoxin: preparation, separation and characterization. Anal Biochem 80:585-592.

Richardson GP, Fiedler W, Fox GQ (1987) Development of the electromotor system of Torpedo marmorata: distribution of extracellular matrix and cytoskeletal components during acetylcholine receptor focalization. Cell Tissue Res 247:651-665.

Rousselet A, Cartaud J, Devaux PF, Changeux J-P (1982) The rotational diffusion of the acetylcholine receptor in Torpedo marmorata membrane fragments studied with a spin-labelled alpha-toxin: importance of the 43,000 protein(s). EMBO J 1:439-445.

Sanes JR (1982) Laminin, fibronectin, and collagen in synaptic and extrasynaptic portions of muscle fiber basement membrane. J Cel Biol 93:442-451.

Sealock R, Wray BE, Froehner SC (1984) Ultrastructural localization of the $M_{\mathrm{r}} 43,000$ protein and the acetylcholine receptor in Torpedo postsynaptic membranes using monoclonal antibodies. J Cell Biol 98: 2239-2244.

Sealock R, Paschal B, Beckerle M, Burridge K (1986) Talin is a postsynaptic component of the rat neuromuscular junction. Exp Cell Res 163:143-150.

Walker JH, Bonstead CM, Witzemann V (1984) The 43K protein, $v_{1}$ associated with acetylcholine receptor containing membrane fragments is an actin-binding protein. EMBO J 3:2287-2296.

Walker JH, Boustead CM, Witzemann V, Shaw G, Weber K, Osborn M (1985) Cytoskeletal proteins at the cholinergic synapse: distribution of desmin, actin, fodrin, neurofilaments, and tubulin in Torpedo electric organ. Eur J Cell Biol 38:123-133.

Witzemann V, Boustead C (1982) Changes in acetylcholinesterase molecular forms during the embryonic development of Torpedo marmorata. J Neurochem 39:747-755.

Witzemann V, Richardson G, Boustead C (1983a) Characterization and distribution of acetylcholine receptors and acetylcholinesterase during electric organ development in Torpedo marmorata. Neuroscicnce 8:333-349.

Witzemann V, Schmid D, Boustead C (1983b) Differentiation-dependent changes of nicotinic synapse-associated proteins. Eur J Biochem 131:235-245.

Woodruff ML, Theriot J, Burden SJ (1987) $300 \mathrm{kD}$ subsynaptic protein copurifies with acetylcholine receptor-rich membranes and is concentrated at neuromuscular synapses. J Cell Biol 104:939-946. 